\title{
Fifty Years of ICBP
}

Jean Delacour

Founded in 1922, the International Council for Bird Preservation has this year celebrated its jubilee. The author, distinguished ornithologist and naturalist and the last founder alive today, has been a leading figure in the Council's work throughout the fifty years.

As early as 1921, Dr Gilbert Pearson, then president of the National Audubon Society in America, came to my home at Clères, in France. $\mathrm{He}$ believed that it was time for bird preservation to be organised on an international level and he wanted my help, which of course, I immediately promised. There were active bird protection societies in several countries but their efforts had never been co-ordinated.

Dr Pearson also met two prominent conservationists in the Netherlands, P. van Tienhoven and A. Burdet, and in England, Viscount Grey of Fallodon, Dr Percy Lowe and a few others. As a result, we met in London at the house of Mrs Reginald McKenna in June 1922, and ICBP (CIPO in French) was finally organised, with Dr Pearson as president. We soon had a number of national sections, mostly in Europe at first, then in other continents, and we started holding meetings in Paris in 1923 and in Luxembourg in 1925.

We grew up rapidly. A continental European section was established under my chairmanship. The late J.M. Derscheid became secretary in 1928, succeeded by Comte Leon Leepe in 1935 as general secretary. Miss Phyllis Barclay-Smith, who had been very active both in Great Britain and on the international level, became general secretary a little later; she still manages our activities today, and is responsible for most of our progress. I succeeded Dr Pearson in 1938, and handed the presidency on to Dr Dillon Ripley in 1958.

I can look back with some satisfaction on the results of fifty years.

First of all, ICBP has promoted an international approach to bird preservation, showing that birds, particularly migratory species, belong to all countries, each nation having a duty to conserve them. Continuous exchange of views between national sections has resulted in better local measures and in international agreements. Situations and an urgent need for action have been discussed at meetings held every other year. For instance, a new Convention for the preservation of European birds was elaborated in Paris in 1950; it came into force in 1963, most countries having then signed it. At a meeting in Tokyo in 1960, the Asian continental section decided to promote a similar treaty for the Pacific area. The first result has been the establishment in 1972 of a convention between the USA and Japan.

A number of special projects for the protection of rare and threatened species have been, and still are being, undertaken, all over the world, some having already had spectacular results. Improved regulations for the capture and hunting of so-called gamebirds, particularly waterfowl, are one of our most important interests, as also 
is the fight against oil pollution. When IUCN was founded in 1948, an informal agreement was drawn up with the much older ICBP for close cooperation, the work of the Survival Service Commission being primarily the responsibility of the latter so far as birds are concerned. We have today 61 national sections throughout the world and each year new ones are formed, as local need increases together with human realisation of the threat to the very existence of birds in the world.

\section{The Turtle Agreement that Failed}

In this quotation from an article in Audubon, Dr Archie Carr describes what happened to the 1969 agreement between three Caribbean countries to protect the green turtle Chelonia mydas.

To date, there is no international programme protecting a [turtle] species throughout its range. There almost was. The world's first approach to a closed system of migratory sea turtle protection almost materialised in 1969. Disturbed by the poor nesting season at Tortuguero [in Costa Rica] for 1968, and urged on by expressions of concern from a great many people, a group of high-level delegates from Costa Rica, Nicaragua, and Panama met in a conferencia tripartita in San Jose. Nicaragua was there because, according to calculations based on our tag returns, at least two-thirds of the Tortuguero nesting colony is derived from the extensive turtle grass pastures off the coast of Nicaragua. Panama is a resident ground or migratory station for perhaps half of the remainder. So those three countries together could almost certainly insure the survival of Chelonia in the western Caribbean.

After three days' deliberations, the delegates agreed to call a three-year moratorium on turtling in all their home waters, while they worked out a permanent plan that would give Costa Rica, custodian of the nesting ground, a fair share of a strictly controlled yearly harvest without raiding the nesting colony. Then they went home to obtain what was expected to be automatic ratification. When Billy Cruz, Costa Rican representative of the $\mathrm{CCC}$, cabled me the news I happily telephoned colleagues who for years had been hoping that some such thing would happen. I wrote IUCN headquarters, too, suggesting that congratulations were in order, and there was great rejoicing. The day of international sea turtle conservation had dawned.

Only it hadn't. What Nicaragua did was sweep the San Jose agreement under the rug and build two big, modern, turtle processing plants, kick out the Cayman turtle schooners, and seduce the Miskito Indians - the Turtle Indians, probably the most specialized turtle culture in the world - into killing feverishly for the factories. Now the Miskitos are taking home a little cash instead of meat, and with it buying an inadequate diet to replace the good one provided for ages by the turtle colony with which their society had evolved. Dr Bernard Nietschmann of the University of Michigan has a forthcoming article on this debacle in the Joumal of Human Ecology. It is a hair-raising story, not only because of what is happening to the Indians and the turtles, but because the development killed the rising resolve of the Costa Rican officials to curb the turtling at Tortuguero. 
For Costa Rica also has two turtle processing plants. They are supplied by boats that cruise along the nesting shore from June through August and harpoon the mating pairs or the females going ashore or returning through the surf. Taking turtles on the beach has been illegal for twelve years. But the harpoon boats come in so close you might as well turn the hunters loose on shore.

Two special aspects of this situation make it stick badly in my craw. One is the absence of any extenuating ignorance by the parties involved as to what they are doing. Chelonia is the best known of the sea turtles, and the life cycle of the Tortuguero nesting colony is better known than that of any other population. Both countries know that Costa Rica has charge of the only green turtle breeding ground remaining in the western Caribbean, and that the Nicaraguan pastures are populated by turtles that hatch on the Costa Rican shore and nowhere else. This simple ecologic picture has been repeatedly made plain. And still they continue to subject the declining resource to growing exploitation. The other bitter pill is that both countries are depriving the poor coastal people of turtles they desperately need, while at the same time espousing an export industry that is bound to obliterate the resource:

From Audubon, magazine of the National Audubon Society; copyright (c) 1972.

\section{Grant that foiled the Turtle Poachers}

A grant of $£ 700$ from the ORYX $100 \%$ Fund to Costa Rica National Parks, to buy the engine for a patrol boat, made it possible for the guards to ensure that there was no poaching at all this year on the green turtle nesting beaches in the Tortuguero National Park. The grant was made possible by a special donation of $£ 500$ to the Fund from Christopher Cadbury. The money was sent immediately, with the result that the boat was completed in time for the nesting season, which, as Dr Archie Carr had been able to predict, proved to be an outstanding one. The Head of National Parks, Ing. Mario A. Boza, in a letter thanking FPS, writes that, at the height of the season, green turtles were coming up the beach to lay in hundreds every night. He adds that, from what is known of the turtles' nesting cycle, next season may be a poor one, and it will be equally important to protect those that come.

An important aspect of the ORYX 100\% Fund is that small grants can be made quickly, and the case of the turtles at Tortuguero shows how valuable this flexibility and quick working can be.

\section{Hawksbills Nesting off Queensland}

The discovery of hawksbill turtles nesting on Long Island, in the Torres Strait, off Queensland, is the first record of this turtle nesting in Australian waters, reports Dr Robert Bustard. The turtles are fully protected in Queensland (by a law passed in 1968), and Long Island is an aboriginal reserve. The Torres Strait islanders do not eat flesh.

\section{Green Turtles}

Synopsis of Biological Data on the Green Turtle Chelonia mydas, No 85 in FAO Fisheries Synopsis series, is by H.F. Hirth. The first of the series on commercially important marine turtles, it gives a thorough survey of the known information, including ranching and farming, and draws attention to the major gaps. 